\title{
Debating Dutch Research Universities: An investigation of Various Viewpoints
}

\author{
R.A.P. Bernabela, P.H. Bles, A.M. Bloecker, D.J. DeRock, M.W.J. van Es, M.L. Gerritse, T. \\ de Jongh, W.J. Lansing, M.A. Martinot, J.M.M. van de Wetering \\ Radboud Honours Academy of the Radboud University Nijmegen
}

\begin{abstract}
There is disagreement over who should have primary influence over Dutch university education and how it should be implemented. The Dutch ministry of science and education has published various reports on how to improve university education by listening to various stakeholders; however, this has not been done sufficiently. Differences in opinions between the stakeholders groups are ignored.

Recognizing this gap in stakeholder analysis, this paper focuses on the question: To what extent do the views of different stakeholders vary regarding university education? Based on previous research, we distinguish five stakeholder groups: the government, business sector, university faculty and administration, students, and the societal sector. We conducted in-depth interviews with representatives from each stakeholder group and distributed a questionnaire.

Our results show that university staff and administration is the most important stakeholder and therefore should have primary control over university education. However, there are important differences in the opinions of the stakeholder groups. For example: Students are concerned with personal development during their education. The business sector focuses on opportunities for students to do internships whereas the university faculty members express concern that focusing on the labour market puts undue pressure on students and compromises the quality of education.
\end{abstract}

\section{Introduction}

After several hundred students from the University of Amsterdam took up the Bungehuis mid-February 2015, police stormed the building and the students were either chased out or arrested. Only a few days later, students invaded the famous Maagdenhuis building of the university. Student groups demanded more democratic elections for the university board and more investment towards higher quality performance in future years. In March, staff of the University of Amsterdam joined the protests. They called for democratisation of the university and a university that combines research and education, instead of a two-tier track of separate research and education [5]. By mid-April the students were forced out of the Maagdenhuis and the chair of the Executive Board, Louise Gunning, stepped down.

This example can be placed within the wider debate on teaching and research at Dutch universities. At the centre of this debate is a disagreement over who should determine university education in the Netherlands and how this education should look [1], [3], [6], [15].

This discussion on various topics concerning Dutch university education reached a first climax when the Commission Veerman published a report in 2010 (Committee on the Future Sustainability of the Dutch Higher Education System [4]. In this report, the Commission stated that Dutch universities fall short on adequately stimulating students to be highly motivated to successfully finish their studies. Dutch universities would never reach the top international level if, among other things, they miss out on bridging the gap between the labour market and universities. The Veerman report states that it is important for the Netherlands to focus on university education and that the country should strive for Dutch universities to reach the top as universities are to be seen as the backbone of the Dutch society.

Following the Veerman report, the Dutch Ministry for Education, Culture and Science (OCW) set forth their aim to improve university education and their desire to downsize the current gap between universities and the economy and society in future years [9]. With these statements and aims, both reports have provoked an uproar of responses from think tanks and the media.

We believe that both the Veerman report and the report from the ministry as well as more recent analyses lack essential elements needed to fully understand, describe and analyse Dutch university education. One example of a very recent report on Dutch university education is provided in the Wetenschapsvisie 2025 [9]. As part of this agenda, the media and various think tanks and stakeholders of universities express their concerns about science in general. Although the views of these stakeholders are briefly mentioned, opinions on the education and curricula are vague and thinly elaborated. Next to the media and think tanks, the voices of representatives from the business sector and the students themselves could be more explicitly taken into account. 
However, they also form an important group of stakeholders and therefore need to be fully part of the discussion on the content of Dutch university education. Besides not taking all stakeholders of universities explicitly into account, the Wetenschapsvisie 2025 takes too narrow of a view while describing the different views of the stakeholders. This view on elaborating the various views of stakeholders creates a gap in the analysis of Dutch university education as all these stakeholders play a major part in shaping and creating Dutch university education.

By recognizing this gap in stakeholder analysis, the aim of this report is to bring attention to the wide range of perspectives on the incorporation of roles to be taken within Dutch university education. While noticing and categorizing the various stakeholders of university education in the Netherlands, this report gives a long-awaited analysis on the mind-sets of important players within the field of shaping university curricula and education.

This aim of has led us to formulate the following research question: To what extent do the views of different stakeholders vary regarding university education?

\section{Method}

To answer the main research question we made use of a quantitative questionnaire as well as qualitative interviews that we held with the five distinguished stakeholder groups. Based on several governmental reports [4], [9], [11], we distinguish five groups of stakeholders: government, university faculty and administration, students, the business sector and the societal sector.

Firstly, since the government is the biggest financial contributor to universities and education in itself is a major policy terrain of the government, we interviewed 11 politicians of various Dutch parliamentary political parties and the director and staff of the Dutch-Flemish Accreditation Organisation (NVAO). Secondly, the university staff and administration itself are distinguished as a stakeholder group, since together possess expertise on the content and structure of education. The university stakeholders are professors, lecturers, rector magnifici and staff of the university. In total we interviewed 8 people from the university staff.

Thirdly, the students are important to consider since they are the ones participating in the education at universities. The student stakeholder group consists of interviews with students, some of whom are members of student councils or other organisations related to students. There were a total of 12 interviews with students.

Fourthly, the businesses are in play since they influence the university by providing grants to research. The business interests in university education were covered by 10 interviews with employees and directors of large- to mid-range and small companies in the Netherlands.

Lastly, the university has a public service mission. So, for the society at large, 9 interviews with opinion makers and people on the street were conducted.

All interviews took place between October 2014 and February 2015. A grand total of 50 interviews were conducted.

As for the quantitative questionnaire, we conducted an online snowball-sampled questionnaire to get a broader picture of the opinions of various stakeholders within the arena of university curricula. In total 196 questionnaires were filled in. The number of students among the respondents was 109 . The responses on the questionnaire ranged in time from October 2014 until January 2015.

\section{Results}

In this section, the most important results from the interviews are elaborated. They are organised according to five different topics that provide a path for reviewing the various opinions of stakeholders regarding university curricula and their inclusion into the Dutch university system. These topics are as followed: Goal, Importance of Stakeholders, Quality of University Education, Differentiation of University Education and Accessibility of University Education.

\subsection{Goal}

This paragraph elaborates on the different opinions on what the goal of universities should be according to the different stakeholders. The goals of universities are closely connected to the goals of curricula as well as the goals of the different study programs. The opinions on the goal of university education of the different stakeholders are stated in the following paragraphs.

3.1.1. Education and Research. All stakeholder groups, except for the business sector, mentioned that providing education and performing research should be the two main goals of a university. These two goals are also the traditional goals of a university. Interviewees from the society group mentioned that, although both should indeed be goals of a university, providing education should take precedence over doing research. Regarding research, many of the stakeholders mentioned that fundamental research should not be pushed aside by applied research.

3.1.2. Labour Market. While most interviewees agree about these more traditional goals, most of the interviewed companies believe that the main goal of 
universities should be to prepare students for the labour market. Students should gain knowledge in their field to be able to acquire a job within the business sector. In contrast, most interviewees from the other stakeholder groups explicitly state that education for a job should not be the main goal of the university. Interviewees from the university group and a few government officials thought that the focus on the business sector is, and should be, the main difference between universities and universities of applied science (HBO).

The commission Veerman stated that the role of potential employers is important in determining curricula, because it enforces the professional profiles of education programs [4]. In contrast, government officials generally thought that only for study programmes with a more professional nature (for example law, medicine, accountancy), the goal of a university should be more oriented to the needs of the labour market. By thinking about the goal of a university in relation to the job market in this way, the government officials take a more differentiated position than the other stakeholders.

Next to the aforementioned goals, all stakeholders besides the business sector note that the personal development of students represents an important goal of a university. Especially students regard personal development as being of great importance.

3.1.3. Society at Large. In the interviews, serving society at large was often mentioned as an important goal of universities. Some interviewees mentioned this as a goal on its own, while others mentioned it as a goal that must be reached by investing in personal development and critical academic skills of students. Seeing university education as a means to develop critical academic skills is explicitly mentioned by some government officials. They state that students are trained to think critically as well as develop their personality to then be able to contribute to society at a later stage of their lives. Learning academic skills is a notion that is also recognised by the business sector. In contrast to government officials, who see the personal development of university students as a critical point for society, university professors primarily connect the development of academic skills to performing research, while only later noting its benefits for the business sector and society in general.

In sum, the main goal of a university is generally considered to be providing education and performing research, with the former often being regarded as most important. Regarding education, certain other goals, such as personal development, can be distinguished. In contrast to the other stakeholders, the business sector states that preparing students for the labour market should be the main educational goal. All stakeholders agree that the ultimate goal of a university is to benefit the society at large in some way.

\subsection{Importance of Stakeholders}

While identification of the goal of universities is of great importance, more concrete questions regarding the development of university education need to be answered. It is therefore crucial to determine how the views of different stakeholders vary regarding university education. The importance of stakeholders is elaborated in this part of the section.

3.2.1. Influence of the Universities. All interviewees agree on the voice that universities should have in the development of curricula. This includes a general agreement that research staff and lecturers have expertise in their field and know what should be taught and what competences their students should obtain. Because of that, they, according to all stakeholders, should be the ones to have the most influence on university curricula. This opinion is also supported by the results of the questionnaire; $87 \%$ of the non-students agree that the university should have a strong influence on the curriculum.

3.2.2. Influence of Students. From the interviews with students it is evident that they themselves believe their influence on university curriculum should be limited. Because a certain level needs to be safeguarded, the students believe that researchers need to have the final say in shaping university curricula. Alongside the opinions of the students, a general consensus by the university stakeholders was that students need to have some influence on the curricula. A university should listen to students, but should also take responsibility in the end. Half of the respondents to the survey representing society agree that students should have a strong influence on curricula. Influence of students on curricula was not an issue in the interviews with people from the business sector. They propose that all stakeholders have to work together to determine university curricula and that there is no primary stakeholder.

3.2.3. Influence of Government. Students think that the role of quality assurance from the government is good. Nevertheless, the government should not determine the specific aspects of curricula, because they are too 'far away' to know the details.

Representatives from the government sector agree on this point. As the government is the most important financial stakeholder of universities [10], it should definitely have some say on the work that goes on within them, but the representatives also note that universities should still have substantial freedom. Only a few interviewees of the business 
sector had an opinion about the government having influence on curricula. They agree that the government should have some influence, but it should be limited.

3.2.4. Influence of Businesses. The opinions on whether businesses should have influence vary. Students agree that businesses should not have any direct influence on curricula at all. Their assistance should be limited to providing internships and supporting research. Various students think that the priorities of the business sector are different from the priorities of the academy. The different priorities would lead to narrow course outlines which would undermine goals of universities such as personal development and critical academic thinking. For the more practical study programmes, the students highlight that it would be appropriate to take the views of companies into account, as for these study programmes, businesses benefit more directly.

Interviewees from the university stakeholder group generally agree on the opinions of the students. Although several people see more relevance of corporate influence in technical universities, they are mostly opposed to influence from the corporate world. This comes from the idea that universities in particular train students to have general analytical skills relating to research.

Government officials have different opinions regarding the influence of business on curricula than students and universities themselves. In fact, most people from the governmental sector agree that there should be a limited amount of influence of businesses, but how much exactly differed per person.

In contrast, members of the business sector agree that businesses should have more influence on universities. They consider the primary goal of a university to be to prepare students for the labour market, which can only be achieved if there is a strong connection between the universities and potential employers.

All in all, most stakeholders agree that the university should have the most influence on universities' curricula. Most people also highlight that students should have some influence, although this was not mentioned by the business sector. The business sector thinks that it needs more influence on curricula, but the other stakeholder groups generally disagree. The government and students agree that the government should continue to monitor the general quality level, but should not focus on the specifics of the curricula.

\subsection{Quality of University Education.}

While in February 2015 students and university staff in Amsterdam fought for democratisation of the university and a shift from financial to educational goals, there is an absence of such strong demands by other stakeholders [7]. The stakeholders' opinions on different aspects that determine quality are highlighted in this section.

\subsubsection{Current state of University Education.} Interviewees from all sectors agree that the current state of university education in the Netherlands is excellent. However, they also think there is room for improvement and they all have their own criticisms. Students say there is a tendency in the Netherlands to think that the best researchers are also the best teachers, which according to them is not necessarily true. Still, they state that lecturers should also do research because scientific education and research are closely related. Therefore, it is important to motivate researchers to teach, for example by giving recognition or even grants for good teaching, independent from research.

The university sector is especially in favour of $\mathrm{T}$ shaped professionals (the vertical bar of the $T$ represents the depth in a single discipline and the horizontal bar the ability to collaborate with other disciplines). One critique they mention is that master programmes for most studies in social sciences are too short, caused by an even bigger issue: the general trend of increasing pressure on students, which also reduces the possibility for personal development.

Government officials are particularly in favour of optional excellence programmes because they enable universities to match students' individual talents and desires. Furthermore, government officials criticise excessive focus on research compared to education and too much pressure on efficiency overall. This has negative influences on the quality of university education, which accompanies complaints of too few contact hours in some study programs. The focus on efficiency also means that universities are hesitant to differentiate and organise small study programmes because they are relatively inefficient.

In contrast, members of society generally do not have an opinion on the quality of university curricula; most interviewees from the societal sector are not related to universities in the Netherlands.

In sum, all sectors have particular opinions on the way quality could be improved in the future. While these judgements differ between and within the various stakeholder groups, they all agree that the current Dutch system is of premium quality.

3.3.2. Work Experiences. Practical experience is more important to some stakeholders than to others. These experiences mostly refer to internship opportunities as part of the curricula of study programmes. Within this part of quality of university curricula, two stakeholders put a lot of emphasis on the importance of work experience at Dutch universities. 
Representatives from the business sector think that most universities are highly qualified to educate students to contribute to the labour market. Concerning university curricula, interviewees from the business sector do not know much about the way it is organised. However, they all agree that they are able to rate university graduates on their capacities when they hire them.

When it comes to rating students, companies especially criticise the universities' focus on theoretical knowledge. Students have too little work experience and some of them are concerned about students missing the reality of working life. The lack of practical insights into the business sector also forces businesses to educate students even after they graduate.

However, looking at the general answers of companies about internship opportunities, most companies agreed on internships being a good way for students to get to know the labour market, but only a few mentioned that their company actually provides these opportunities, while nationwide companies provide internships for an average of 3.6 students a year [13]. Whether the companies that did not mention their internship opportunities actually did provide them is unknown.

The lack of practical knowledge during the bachelor and master is also an aspect raised by university students. For most of the students, internships during the bachelor periods would help them to orientate on the job market. Furthermore, an idea would be to split universities into students who want to become scientists and students who want to work in the business sector after graduating. This way, students know their options and will then be able to choose for the option that fits best for them.

The university, government and societal sectors did not mention the gap between university and the labour market and did not call for more internships.

3.3.3. Quality Assessment. Nowadays, the quality of universities' study programs is officially assessed by the quality care of the institution and by the NVAO, an independent governmental body. Interviewees from most sectors see the necessity of quality checks. However, there were some requirements and complaints as well. The business sector argued that accreditation should not only be performed by a governmental organisation but in collaboration with all stakeholders. Students think that their position should be stronger in this process. They believe that they are left out of the accreditation process, while at the same time they play an important part in university life. According to the students, by giving them a weak position within the process the accreditation leaves out essential parts of its analysis.

From all stakeholders we heard complaints about the amount and detail of accreditation. Firstly, it is quite difficult for universities to improve the quality of their curricula while the definition of quality is illdefined and seems to be based more on intuition than on proper definitions. Further, according to the interviewees accreditation nowadays is too strict and too much focussed on paperwork, which causes universities to focus on that instead of actually trying to improve quality. According to some interviewees from the university sector the increasing bureaucracy is partly caused by the increasing demands for regulations and standards by students. However, the accreditation procedure enforced by the NVAO is still responsible for a large part of the bureaucracy. To relieve the bureaucratic burden, the university sector wants more trust on the quality of their education and some also plead in favour of institutional accreditation.

These discussions lead to the conclusion that there is a gap between the concerns of the university sector, intentions of the NVAO and the accreditation process they actually carry out. While various sectors complain about the sometimes inefficient methods of quality assessment, the NVAO sees itself as very open-minded to new proposals.

Because of this perceived gap, one needs not only to think in terms of the accreditation process applied by the NVAO as it comes to accreditation of university curricula. By taking the opinions of all university stakeholders into account, accreditation can become more effective and efficient.

\subsection{Differentiation of University Education.}

Differentiation is a key factor in achieving higher quality in research and education. Each university in the Netherlands offers a variety of study programmes. The committee Veerman [4], defined three types of differentiation: differentiation in the structure of the educational system, differentiation in the disciplinary profile of the university and in the manner and extent of specialisation in the content of the study programmes [4]. In the interviews, the most discussed forms of differentiation were those regarding specialisation of the curricula and the disciplinary profile of the universities. Moreover, differentiation was sometimes used with regard to the level of education. Therefore, it should be taken into account that the interviewees may have interpreted the notion of differentiation in different ways.

3.4.1. Specialisation in Study Programmes. Differentiation in the form of specialisation can occur in two ways, the first and mainly discussed being specialisation and focus of the entire curriculum. This kind of specialisation has already been applied as some universities have introduced thematic instead of disciplinary programmes. The University of Amsterdam, for instance, has started a bachelor on Future Planet Studies. Members of the 
NVAO are in favour of this, as they think that universities should also strive to tackle general problems in society rather than only focus on the traditional academic fields. However, these kinds of programmes may threaten to lower the overall level of the discipline as the broader discipline's knowledge may be compromised.

Next to issues regarding thematic programmes, in several interviews with students a demand for more specialised curricula was noticed. However, then it should become easier for students to follow courses at different universities.

Furthermore, it is highlighted that some studies are too broad and are not specific enough to form a student who has a high level of theoretical knowledge. This causes a loss of focus on what is really essential. An interviewed researcher and columnist think that specialisation on subjects and study programmes on the level of university would lead to a higher quality of curricula and to students with more theoretical knowledge. To achieve this, cooperation between different Dutch universities should be increased.

An example of the specialisation of entire curricula is given by the difference between programmes at traditional and technical universities. Regarding this topic, some companies did state to specifically search for graduates who have obtained their degree at a technical university, while others said to accept graduates from a wide variety of study programmes. Most of them, however, expressed the demand for a broad rather than specialised education in which the student learns the basics of the field.

Specialisation can also occur in the form of the focus of existing courses. This means that the curricula themselves may be broad, but individual courses are focussed on specific aspects of the research fields. However, the two forms of specialisation can be closely related.

Some interviewed members of a political party do raise a demand regarding specialisation in general. They mention that universities should be transparent about their choices in specialisation and about their strengths and weaknesses.

\subsubsection{Educational Structure. Next to} differentiation regarding specialisation, differences in the educational structure applied by universities can also lead to differentiation in the university landscape. For example, universities might choose to provide a study programme that is oriented more on group projects rather than lectures. Another example is given by the extracurricular excellence programmes started by universities. Students and members of the NVAO are in favour of this kind of differentiation.

In an important development regarding this form of differentiation, some of the Dutch universities, like the ones in Utrecht and Maastricht, have started university colleges. These programmes aim to provide unique bachelor programmes that are similar to the ones taught at liberal arts colleges in the United States, and are specifically aimed to be international.

Some of the interviewees were enthusiastic about these university colleges while others had a more critical opinion. One of the members of the academic staff commended the heavy study load of the programme, but expressed some concerns on its broadness. An interviewed rector does not see the added value of the university colleges as the Dutch secondary schools already offer a broad education of high enough quality. He concluded that we do not want a jack of all trades and a master of none.

3.4.3. University Profiling. Differentiation can also manifest itself when universities choose to focus on a specific set of disciplines. Regarding this form of differentiation, a member of the House of Representatives commends the distinct role the University of Wageningen has compared to the other Dutch universities, as it is specialised only in the agricultural sciences. Additionally, a staff member of the Radboud University, mentions that if universities desire to excel, choices in the profile of a university should be made. He states that it is impossible to be open for all disciplines, perform at the current level and at the same time be in the top league. However, he does not have an opinion on whether universities should strive for this.

The results of the survey show that $57 \%$ of the representatives of society think that universities should differ more and should excel in different fields.

3.4.4. Level of Education. Finally, differentiation may be used when referring to the diversification of the level of education at universities. Many interviewees are opposed to great differences in the level of education. Results from the questionnaire show that a large part of the students (70\%) think that the level of education should be the same at all universities. Furthermore, an interviewed member of the house of parliaments mentions that the previously discussed forms of differentiation will not necessarily generate differences in the level of education.

Many interviewees stated that there should at least be a lower bound for the level of education. Still, interviewees often regarded the quality of education at all Dutch universities to be so high that a proper education is guaranteed no matter which university is chosen.

On the whole, differentiation in the university landscape in the sense of specialisation, structure of education and disciplinary profiling of universities is preferred by many of the interviewees. Others express their concerns about the consequences, like a 
potential decrease in the quality of education. Furthermore, differentiation in the level of education is generally considered to be unfavourable. Nevertheless, in recent developments universities have already started to profile themselves more and more to strengthen their position as competition increases.

\subsection{Accessibility of University Education.}

It became clear that accessibility is differently influenced by selection procedures, the idea of elite universities and university rankings. The stakeholders' opinions about accessibility are highlighted here.

3.5.1. Selection Procedures. Universities use different selection procedures to manage the high number of pupils who want to go to university. The numerus fixus and matching, for example, are procedures to select students before they enter a university. The former limits the number of students when the number of applicants greatly exceeds the number of available places. With matching, students are interviewed to find the best suitable study programmes. Based on that, students can be advised on their choice or a specific study programme. These can be selective in the form of obligatory motivational interviews to select students with expectations and skills that are in line with the programme's content and requirements.

A selection procedure during the education is the "Bindend Studie Advies" (Binding Study Advise, BSA), where universities demand students to cease their study when their results are insufficient.

The examination of selection procedures before and during education is seen differently between and within stakeholder groups.

Stakeholders generally agree that selection procedures like the BSA and the numerus fixus have some disadvantages like denying students who would otherwise have been able to obtain their degree. Other options, like matching and motivation interviews, are regarded as being more appropriate selection procedures to support students' motivation and their competences. Taking these parts together, stakeholders therefore believe in conducting interviews and making right choices based on personal interviews instead of just resting their selection on grades. In this way, the most appropriate students for the specific studies can be selected and universities can prevent high drop-out rates.

3.5.2. Elite Universities. There is an ongoing debate of whether the Netherlands should support one or two universities to compete with the international rankings and thus become elite universities. These universities may have advantages and disadvantages, like negatively influencing accessibility [13], [15].
Many of our interviewees also discussed these issues.

The results of the interviews and the survey show that the majority of the interviewees are not in favour of the idea of elite universities in the Netherlands. There are some exceptions though. For example elite universities are regarded positively by some respondents from the business sector. The business sector states that these universities are an advantage for the Netherlands as a whole because they can excel in different fields. This is supported by the results from the survey from the society group. Half of the asked people agree that there should be one or two top universities in the Netherlands to be able to compete on international rankings.

Another positive point is made by a government official who states that elite universities would provide an incentive for other universities to also want to exceed. Moreover, one student argues higher ranked elite universities might attract more foreign students. Nevertheless, all proponents argue that the implementation of elite universities should not be at the expense of the capital of other universities and that accessibility has to be maintained for everyone.

A negative point about elite universities addressed by every stakeholder group is the concern about reduced accessibility. For example, students state that accessibility would be reduced to those wealthier, who can afford paying higher tuition fees, which may also result in social elite. Furthermore, they worry that if more money is given to only a few universities, a large difference will be created in quality between universities.

Some alternative ideas to elite universities were presented during the interviews. One idea, given by government officials, is to encourage excellence programs at every university. Furthermore, they argue that every university should be a top university, albeit in their own disciplines. A similar idea is highlighted by representatives of society, where an elite would only be preferred among research institutions.

3.5.3. Rankings. As described above, some of the interviewees noted that elite universities might lead to an increased position in the international rankings. There are many different college and university rankings, although only a few are truly influential. When looking at the results of the interviews, it can be seen that none of the stakeholders is in favour of these rankings. Both government officials and representatives from society emphasise that these rankings focus too much on quality of research and too little on quality of education. Representatives of the business sector agree that these rankings cannot be used as an indicator of a high level of university education.

Students do not see rankings as important as well. None of the interviewees considered university 
rankings when they chose their study. They argue that rankings might be more important if one wants to go to a foreign country or if one wants to obtain a PhD.

One can conclude that all stakeholders generally think that elite universities are not a good idea, due to reasons like a decrease in accessibility or the creation of social elite. Moreover, rankings are mostly found useless and they are said to focus too much on research quality instead of education quality.

\section{Conclusion}

This research investigated to what extent stakeholders' (business, government, students, society and university) views vary regarding university education in the Netherlands and which recommendations follow from these views. From our results we can conclude that the university- which includes both staff and administration - is generally seen as the most important stakeholder. Therefore, we take the position that universities should have primary control over the content of curricula. However, universities cannot act without the cooperation of the other stakeholders, because they are embedded in society. Therefore, these stakeholders also play important roles in university education and have to be taken into account. The government for example safeguard a certain level of quality, businesses are important providers of internships, students are essential in fine-tuning university curricula, and the valorisation of universities in society when designing the curricula is also to be considered. Based on the body of data from the semi-structured interviews, the survey and subsequent made conclusions we are able to make various recommendations, which can be found in the extended version of our report [2].

Although the university itself is seen as the stakeholder that should have primary influence on the curricula of universities, this does not mean that other stakeholders should not have any influence. Other stakeholders might still have an indirect influence. An important issue that is mentioned by students as well as the business sector is the gap they experience between study and work. When students finish university, they often do not know what to expect from the labour market. They would like to be informed more by both the university and businesses about possibilities on the labour market, and they would like this to be related to the content of the study programme. In this way, students could get an idea of the practicalities of the labour market.

Furthermore, businesses notice a lack of practical skills in students that apply for a job right after graduation. They want students to be trained in practical skills that are relevant in the field. Students can be prepared during their Bachelors and Masters by doing practical work and by focusing more on the organisations in which they might work in the future. It followed from our interviews that both businesses and students thought that students should have the opportunity to do internships, to experience themselves what their field looks like and what kind of extra skills they need to develop during their education to be well prepared. We believe that the business sector expects internship experience from graduated students, but does not provide very many opportunities to gain this experience as the number of available internships is limited.

Across all stakeholders interviewed, the notion of elite universities in the Netherlands has been a significant subject of discussion. It is argued that as two universities in the Netherlands would get more direct funding, these two would reach higher quality and would be internationally higher ranked [1], [12], [15]. Most stakeholder groups, however, think that establishing elite universities in the Netherlands is not desirable. This is in part because all stakeholders agree that accessibility has to be commonplace in the Netherlands and elite universities might decrease accessibility. Instead of arguing for one or two elite universities in the Netherlands, all stakeholders agree that every university should be a top university, albeit in their own disciplines. Quality can be improved by focusing on certain fields in which universities can excel. The Netherlands already has seven specialised universities (the universities of technology in Delft, Eindhoven and Twente, Wageningen University, and the universities of Rotterdam, Tilburg and Maastricht) which are restricted to just one or a few areas (Meza, 2012). Differentiation could then be accomplished in different ways. Firstly, some universities focus on particular fields of expertise, such as the technical university of Eindhoven. Secondly, universities could use another educational model, for example either emphasising more on group work or on the theoretical parts of a study.

As it comes to quality assessment, a gap can be seen between the ideas the NVAO has about accreditation and the way it is perceived by universities. For example, the NVAO expresses eagerness to reduce paperwork in its accreditation procedures and is open to ideas for improving accreditation, but other stakeholders, mainly the universities, do not seem aware of this willingness. Since accreditation is about the assessment and improvement of quality, we believe that the bureaucracy should be reduced. By doing that, universities would be more willing to work together with the NVAO in order to achieve a high quality curriculum instead of being reluctant to work with the NVAO.

All in all, our research demonstrates that while the views of stakeholders are diverse, there is a general consensus that universities should play the 
leading role in curriculum design. The university's central goals of education and research are not in conflict with the goals of the other stakeholders but rather complement them. Even where the specific expectations of different stakeholders differ, most still agree that the practical decisions of what and how students should be taught should be made at the level of the university. There are also important areas of agreement that have been overlooked but that are still perceived as conflicts, which points to a lack of communication between stakeholders. This underscores the importance of taking the perspectives of all stakeholders into account when developing university-related policies in the future. Collaboration between all levels of society is crucial for obtaining the highest quality of university education.

\section{Suggestions for Further Research}

It is shown that this line of research adds to our general understanding of the curricula of Dutch research universities. Considerable differences were found between the different stakeholder groups, and there was a relative homogeneity within the groups. Therefore, we recommend that more research should be done using the methods of stakeholder analysis used in this report. Questions could be asked about different aspects of higher education.

Moreover, this Dutch experience offers lessons to other countries as well. As the internationalisation of higher education is occurring faster than ever before, universities throughout Europe and globally are experiencing many of the same pressures. Subjects such as these would be good starting points for further research using the method of stakeholder analysis used in this research.

The distinction between the stakeholder groups was made based on previous research [4], [9], [11]. We divided university into the students on one hand and staff and administration on the other hand. This distinction was made based on the assumption that the goals of the staff and administration overlap. However, an option would be to separate the university staff and administration into two stakeholder groups.

Furthermore, there were some subjects that came up during the interviews that were not considered beforehand, so that these subjects were not polled in every interview. An example is the role of alumni in determining the curricula. This was polled in most of the interviews with students. Among those asked it was generally thought that alumni were not utilised as much as they could be in improving their education. Another important subject that was not brought up in the interviews is the role of trust between stakeholders and how trust between them can be formed and stimulated.

\section{Acknowledgements}

We are grateful for our supervisor dr. Floris Heukelom of the Radboud University for his valuable input and his expert guidance. Our gratitude extends to Noor ter Berg for her organisation of this program. Finally, we want to acknowledge the Radboud Honours Academy for providing us with this unique opportunity.

\section{References}

[1] Bal, R., Halffman, W. (2014, September 1). 'Topuniversiteit leidt tot extreme ongelijkheid', De Volkskrant. Retrieved from http://www.volkskrant.nl

[2] Bernabela, R.A.P., Bles, P.H., Bloecker, A.M., DeRock, D.J., van Es, M.W.J., Gerritse, M.L., De Jongh T., Lansing, W.J., Martinot, M.A., Van de Wetering, J.M.M. (2015). The Debate over Dutch Universities: An Analysis of Stakeholder Perspectives. Nijmegen: Radboud University, Honours Academy.

[3] Brugh, M. A. d. (2014, October 18). Wat kopen we voor die kennis?, NRC Handelsblad. Retrieved from http://www.nrc.nl

[4] Committee on the Future Sustainability of the Dutch Higher Education System [commissie-veerman]. (2010). Threefold differentiation - Recommendations of the Committee on the Future Sustainability of the Dutch Higher Education System. The Hague: Ministry of Education, Culture and Science. Retrieved from http://www. Rijksoverh eid.nl.

[5] De Voogt, S. (2015, March 6). De UvA haalt de deadline van de docenten niet. Dit is wat ze eisen., NRC Handelsblad. Retrieved from http://www.nrc.nl

[6]Flierman, A. (2014, August 25). Goed onderwijs vraagt om de beste bestuurders, NRC Handelsblad. Retrieved from http://www.nrc.nl

[7] Lane, M. (2015, March 9). Amsterdam students and staff demand self-organisation of universities. Redflag. Retrieved March 23, 2015, from http://redflag.org.au/article/amsterdam-students-and-staffdemand-self-organisation-universities

[8] Meza, C. C. (2012). Facts and Figures - Universities in the Netherlands 2012. The Hague: Rathenau Institute. Retrieved from http://www.ra thenau.nl/en/ publications.html.

[9] Ministry of Education Culture and Science. (2014). Wetenschapsvisie 2025: keuzes voor de toekomst. The Hague: Ministry of Education, Culture and Science. Retrieved from http://www.rij ksoverheid.nl.

[10] Rathenau Institute. (2013). Universitaire baten en lasten vanaf 2000. The Hague: Rathenau Institute. Retrieved March 23, 2015, from http://www.r athenau.nl/nc/web-specials/de-nederlandse- 
wetenschap/cijfers/cijfermateriaal/onderzoeksinstellingen. html.

[11] Rathenau Institute. (2014). Future Knowledge. The Hague: Rathenau Institute. Retrieved from http://www.rathenau.nl/en/publications.html.

[12] Schouten, J. (2014, August 26). 'Eén of twee Nederlandse topuniversiteiten leidt tot verarming', De Volkskrant. Retrieved from http://www.volks krant.nl

[13] Souhuwat, S., \& Van der Sluis, B. (2014). Nationaal Stage Onderzoek Bedrijven 2014 Retrieved April 28, 2015, from http://www.nat iona alstageonderzoek.nl

[14] Teunissen, K. (2013, March 12). Report/Niveau Havard naar Nederland? Retrieved March 12, 2015, from http://www.studenten.net/studieleven/nieuws/ 21860/report_niveau_harvard_naar_nederland

[15] Van der Meulen, B. (2014, August 25). 'Universiteiten blijven hangen in de subtop', De Volkskrant. Retrieved from http://www.volkskrant.nl 